\title{
Milk: a postnatal imprinting system stabilizing FoxP3 expression and regulatory T cell differentiation
}

\author{
Bodo C. Melnik ${ }^{1 *}$, Swen Malte John ${ }^{1}$, Pedro Carrera-Bastos ${ }^{2}$ and Gerd Schmitz ${ }^{3}$
}

\begin{abstract}
Background: Breastfeeding has protective effects for the development of allergies and atopy. Recent evidence underlines that consumption of unboiled farm milk in early life is a key factor preventing the development of atopic diseases. Farm milk intake has been associated with increased demethylation of FOXP3 and increased numbers of regulatory T cells (Tregs). Thus, the questions arose which components of farm milk control the differentiation and function of Tregs, critical T cell subsets that promote tolerance induction and inhibit the development of allergy and autoimmunity.

Findings: Based on translational research we identified at least six major signalling pathways that could explain milk's biological role controlling stable FoxP3 expression and Treg differentiation: (1) via maintaining appropriate magnitudes of Akt-mTORC1 signalling, (2) via transfer of milk fat-derived long-chain $\omega$-3 fatty acids, (3) via transfer of milk-derived exosomal microRNAs that apparently decrease FOXP3 promoter methylation, (4) via transfer of exosomal transforming growth factor- $\beta$, which induces SMAD2/SMAD3-dependent FoxP3 expression, (5) via milk-derived Bifidobacterium and Lactobacillus species that induce interleukin-10 (IL-10)-mediated differentiation of Tregs, and (6) via milk-derived oligosaccharides that serve as selected nutrients for the growth of bifidobacteria in the intestine of the new born infant.
\end{abstract}

Conclusion: Accumulating evidence underlines that milk is a complex signalling and epigenetic imprinting network that promotes stable FoxP3 expression and long-lasting Treg differentiation, crucial postnatal events preventing atopic and autoimmune diseases.

Keywords: Epigenetic, Exosome, FoxO1, FoxP3, Milk, MicroRNA, mTORC1, Probiotics, TGF- $\beta$, Treg

\section{Background}

Children who grow up on traditional farms are protected from atopic diseases [1]. Early-life consumption of unboiled cow's milk has been identified as the most protective factor for the development of atopy [2-10]. Farm milk exposure has been associated with increased numbers of $\mathrm{CD} 4{ }^{+} \mathrm{CD} 25^{+} \mathrm{FoxP}^{+}$regulatory $\mathrm{T}$ cells (Tregs), lower atopic sensitization and asthma in 4.5-year-old children [11]. Treg cell numbers are negatively associated

\footnotetext{
*Correspondence: melnik@t-online.de

${ }^{1}$ Department of Dermatology, Environmental Medicine and Health

Theory, University of Osnabrück, Sedanstrasse 115, 49090 Osnabrück, Germany

Full list of author information is available at the end of the article
}

with asthma and perennial immunoglobulin E serum levels [11]. However, the allergy-preventive effectors of milk, which stimulate the development of Tregs remain elusive. Based on translational research we provide six potential milk-derived signalling pathways that could promote appropriate differentiation and maturation of Tregs.

\section{Findings \\ Amino acids}

Milk is the postnatal nutritional environment of all mammals that mediates immune stimulatory functions, especially long-term stable expression of FoxP3, the key transcription factor of Tregs. Milk protein provides appropriate amounts of certain insulinotropic amino 
acids such as essential branched-chain amino acids that induce the secretion of insulin as well as amino acids such as tryptophan that increase hepatic insulin-like growth factor-1 (IGF-1) secretion [12-21]. Both growth hormones synergistically activate the phosphoinosite-3 kinase (PI3K)-Akt pathway. Control of PI3K in Treg cells is essential for Treg lineage homeostasis and stability $[22,23]$. Diminished control of PI3K activity in Treg cells reduces expression of the interleukin-2 (IL-2) receptor $\alpha$ subunit CD25, accumulation of FoxP $3^{+} \mathrm{CD} 25^{-}$cells and, ultimately, loss of expression of the transcription factor FoxP3 in these cells [23]. Excessive postnatal protein intake via infant formula feeding has been demonstrated to increase infant's serum levels of insulin and IGF-1 accelerating growth and weight gain (early protein hypothesis) [24-26]. Rapid weight gain in infancy has been linked to an increased risk of asthma [27-29].

Tregs are a developmentally and functionally distinct $\mathrm{T}$ cell subpopulation that is engaged in sustaining immunological self-tolerance and homeostasis. The transcription factor FoxP3 plays a key role in Treg development and function [30-33]. There is accumulating evidence that insufficient maturation and differentiation of Tregs play a key role in the development of common allergic diseases and autoimmunity [34-39].

Notably, FoxP3 expression is linked to nutrient signalling via Akt-mediated phosphorylation of the transcription factors FoxO1 and FoxO3. Increased insulin/IGF-1 signalling leads to inactivation of FoxO1 and FoxO3a by their phosphorylation-dependent extrusion form the nucleus into the cytoplasm. Both FoxO1 and FoxO3a exert stimulatory effects on FoxP3 expression [40] (Fig. 1). A FoxO3a-binding motif is present in the proximal region of the FOXP3 promoter [40]. The absence of FoxO1 severely curtails the development of FoxP3 ${ }^{+}$Tregs. In addition, the absence of FoxO3 exacerbates the effects of the loss of FoxO1 [41]. Thus, there is compelling evidence that increased PI3K-Akt-signalling blocks FoxP3 expression by sequestering FoxO factors [42]. FoxO transcription factors cooperatively control the differentiation of FoxP3 ${ }^{+}$Tregs [43]. FoxO proteins function in a Treg-intrinsic manner to regulate thymic and TGF- $\beta$-induced FoxP3 expression, in line with the ability of FoxO proteins to bind to FOXP3 locus and control FOXP3 promoter activity [43]. FoxO proteins are considered to play crucial roles in specifying the Treg cell lineage [43]. Genome-wide analysis of FoxO1 binding sites reveals $\sim 300$ FoxO1-bound target genes that do not seem to be directly regulated by FoxP3. These findings show that the evolutionarily ancient Akt-FoxO1 signalling module controls a genetic program indispensable for Treg cell function [44].

Upregulated PI3K-Akt signalling in the presence of sufficient amounts of branched-chain amino acids and

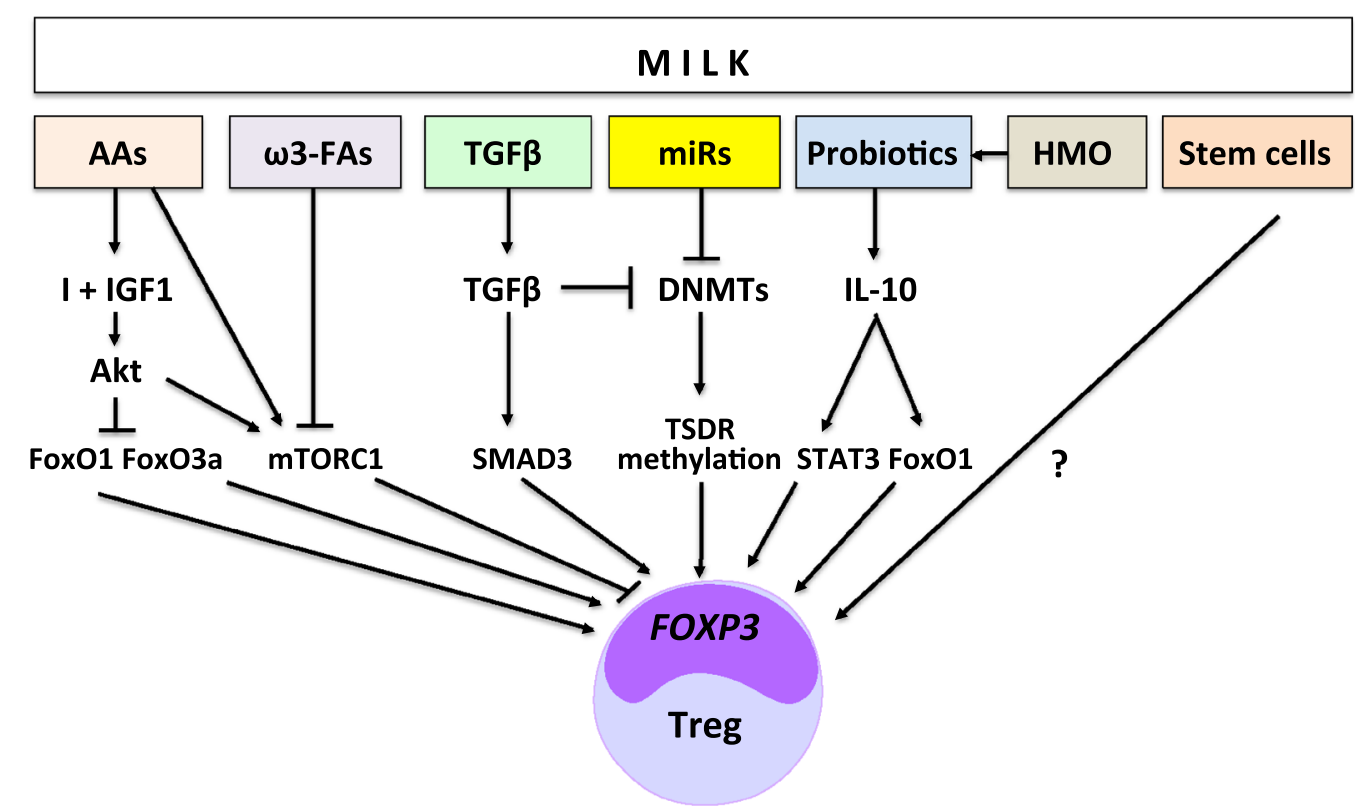

Fig. 1 Synoptic working model for milk-induced FoxP3 expression and regulatory T cell (Treg) differentiation. The transcription factors FoxO1, FoxO3a, SMAD3 and STAT3 all enhance FoxP3 expression. Milk exosomal microRNAs and TGF $\beta$ attenuate DNA methyltransferase (DNMT) expression promoting TSDR demethylation (AAs: amino acids; $\omega 3$-FAs; $\omega-3$ fatty acids; HMO: human milk oligosaccacharides; l: insulin; IGF1: insulin-like growth factor-1; miRs: microRNA-148a, microRNA-29, microRNA-21; mTORC1: mechanistic target of rapamycin complex 1; TGF $\beta$ : transforming growth factor- $\beta$; STAT3: signal transducer and activator of transcription 3; TSDR: Treg-specific demethylated region) 
glutamine increases the activity of the nutrient-sensitive kinase mechanistic target of rapamycin complex 1 (mTORC1) [45-47]. Milk has recently been identified as a signalling system of mammalian evolution controlling mTORC1-dependent translation [48, 49]. Enhanced mTORC1 activity was found in the brain and ileum of mice with cow's milk allergy (CMA) [50]. Treatment with the mTORC1 inhibitor rapamycin significantly increased the mRNA expression of FoxP3 in the ileum and Peyer's patches of CMA mice. A correlation between the extent of mTORC1-mediated S6K1 phosphorylation and FoxP3 mRNA expression in the ileum was demonstrated [50].

Taken together, the Akt-mTORC1 axis controls FoxP3 expression and differentially regulates effector and Treg cell linage commitment [43,51-53]. It is thus conceivable that a well-balanced transfer of critical amino acids via breastfeeding controls Akt-mTORC1-mediated Treg differentiation, which may be disturbed by artificial formula feeding with high protein content $[54,55]$.

\section{Long-chain $\omega$-3-fatty acids}

Part of the asthma-protective effect is associated with the intake of raw cow's milk and was explained by higher levels of polyunsaturated $\omega-3$ fatty acids of farm milk [56]. Remarkably, it has been demonstrated in a mouse model of atopic dermatitis that administration of the $\omega-3$ fatty acid docosahexaenoic acid upregulates the generation of TGF- $\beta$-dependent CD4 ${ }^{+}$Foxp $3^{+}$Tregs $[57,58]$. Furthermore, fatty acids play a role in mTORC1 activation. Whereas the saturated fatty acid palmitate activates mTORC1, the $\omega-3$ fatty acid eicosopentaenoic acid inhibits mTORC1 activation [59]. Thus, $\omega$-3-fatty acids may not only attenuate pro-inflammatory eicosanoid biosynthesis but may exert direct effects on FoxP3 Treg activity. In fact, it has been demonstrated that Tregs transfer $\omega-3$ long chain polyunsaturated fatty acids-induced tolerance in mice allergic to cow's milk protein [60].

\section{MicroRNAs}

Extracellular RNAs and especially exosomal microRNAs are regarded as most important factors involved in the regulation of the immune system [61, 62]. Human breast milk is a body fluid that is highly enriched in mRNAs and microRNAs [63]. MicroRNAs are either packaged with proteins (i.e. Ago2, HDL, and other RNA-binding proteins or wrapped in small membranous particles (i.e. exosomes, microvesicles, and apoptotic bodies) [64-67]. Human, bovine and porcine milk transfer high numbers of exosomes that contain microRNAs [68-70]. Recent evidence indicates that human milk microRNAs primarily originate from the mammary gland resulting in unique microRNA profiles of fractionated milk [71]. Recently, we hypothesized that milk transmits microRNAs (microRNA-155, microRNA-148a, microRNA-29b, microRNA-21) that may induce thymic FoxP3 $^{+}$Treg differentiation thereby preventing the development of allergy [72]. Indeed, farm milk consumption is associated with higher FOXP3 demethylation and higher Treg cell numbers [11]. Stable expression of FoxP3 in Tregs depends on DNA demethylation at the Treg-specific demethylated region (TSDR), a conserved CpGrich region within the FOXP3 locus [73-75]. In contrast, hypermethylation of the FOXP3 gene has been associated with reduced Treg function and allergy [76, 77]. Notably, atopic individuals express lower numbers of demethylated FoxP3 ${ }^{+}$Tregs [78].

There are two potential mechanisms of DNA demethylation: (1) passive demethylation through inhibition of DNA methyltransferases (DNMTs) and (2) active demethylation mediated by ten-eleven-translocation (TET) 2 and 3 [79]. TET2 binding to CpG-rich regions requires the interaction of TET2 with the protein IDAX (also known as CXXC4) [80]. Intriguingly, the CXXC DNA-binding domains can bind unmethylated DNA and recruit TET2 via IDAX [81]. Thus, DNMT inhibition may favour active TET2-mediated TSDR demethylation.

Both DNMT1 and DNMT3b are associated with the FOXP3 locus in CD4 ${ }^{+}$cells $[82,83]$. Remarkably, DNMT1 deficiency resulted in highly efficient FoxP3 induction following TCR stimulation [82]. Importantly, DNMT1 is a direct target of microRNA-148a [84], which is abundant in bovine colostrum, mature cow's milk, and human breast milk $[68,85,86]$. MicroRNA-148a is highly expressed in bovine milk fat and milk fat globules of human breast milk [87, 88]. MicroRNA-148a directly downregulates the expression DNMT1 and DNMT3b, whereas microRNA-21, another abundant microRNA of cow's milk, indirectly inhibits DNMT1 expression by targeting RASGRP1 [84]. MicroRNA-29b increases dose-dependently in human serum after intake of pasteurized cow's milk [89]. MicroRNA-29 targets DNMT3a and DNMT3b [90]. Remarkably, nucleotide sequences of microRNA-148a-3p, microRNA-29b and microRNA-21 of Homo sapiens and Bos taurus are identical (mirbase.org). Kirchner et al. [87] recently suggested that microRNAs of unprocessed cow's milk mediate the allergy preventive farm milk effect. It is of functional importance that most milk-derived microRNAs are transported either in exosomes or milk fat globules [48, 49, 69, 70, 88-93].

It has recently been demonstrated that bovine milk microRNAs (microRNA-29b, microRNA-200c) are taken up in reasonable amounts by healthy human subjects after consumption of pasteurized cow's milk [88]. Further evidence underlines that bovine milk exosomes are able to cross human intestinal cells and vascular endothelial cells via endocytosis $[94,95]$. 
Notably, boiling of raw cow's milk abolishes the allergypreventive farm milk effect [3] and results in substantial loss of microRNA-148a-3p [87]. MicroRNA-155, another important immune regulatory microRNA of milk [72], targets suppressor of cytokine signalling 1 (SOCS1), which maintains STAT5 activity further enhancing Treg differentiation [96]. Boiling of milk may disrupt the protective lipid bilayer of milk exosomes accelerating the degradation of critical milk microRNAs. Furthermore, heat-induced alterations of exosomal membrane proteins may disturb intestinal exosome uptake. Thus, native milkderived exosomal microRNAs via suppressing DNMTs may provide pivotal epigenetic signals stabilizing FoxP3 expression and Treg differentiation.

\section{Exosomal transforming growth factor- $\beta$}

It has been demonstrated that exosomes of cow's milk not only transfer microRNAs but also transforming growth factor- $\beta$ (TGF- $\beta$ ) [97]. The TGF- $\beta$ signalling pathway activates the transcription factors SMAD2 and SMAD3 $[98,99]$. SMAD3 is a crucial transcription factor enhancing FoxP3 expression via binding to the conserved non-coding sequence 1 (CNS1) of FOXP3 [100] (Fig. 1). Experimental evidence reveals that TGF- $\beta$ in the context of T cell receptor (TCR) stimulation induces FoxP3 gene transcription in thymic Treg precursors, $\mathrm{CD}^{+} \mathrm{CD}^{-} \mathrm{CD}^{-} 5^{-}$semimature and mature singlepositive thymocytes [101]. TGF- $\beta$ also converts naïve $\mathrm{T}$ cells into inducible Treg (iTregs) and protects Tregs against apoptosis and destabilization [102]. Importantly, it has been demonstrated that TGF- $\beta$-induced expression of FoxP3 in T cells is mediated through inactivation of the kinase ERK [103]. TGF- $\beta$ via inhibition of ERK activation downregulates the expression of DNMT1, DNMT3a and DNMT3b associated with increased FoxP3 expression [97]. Recently, Arntz et al. [104] confirmed that bovine milk exosomes induce FoxP3 expression and Treg differentiation in murine splenocytes. Thymusderived exosomes as well are able to induce FoxP3 ${ }^{+}$ Tregs in peripheral tissues [105]. Moreover, the incubation of peripheral blood mononuclear cells with isolated human breast milk exosomes increased the number of FoxP ${ }^{+} \mathrm{CD}^{+}{ }^{+} \mathrm{CD} 25^{+}$Tregs [106]. Thus, milk-derived exosomal TGF- $\beta$ acts via transcriptional control and epigenetic regulation of FoxP3 expression. It is noteworthy to mention that deficient TGF- $\beta$ signalling is associated with activation of the PI3K/Akt pathway [107], which suppresses FoxO signalling.

\section{Bifidobaceria and lactobacilli}

Human milk is a source of living bifidobacteria and lactobacilli for the infant gut [108-111]. Bifidobacterium breve, B. adolescentis, B. bifidum, and Lactobacillus plantarum WLPLO4 were isolated from human milk samples $[108,110]$. There is accumulating evidence that probiotic bacteria generate FoxP3 $\mathrm{T}$-cell responses in the small intestine [112]. L. plantarum WCFS1, L. salivarius UCC118, and L. lactis MG1363 upregulate numbers of $\mathrm{CD}_{11 \mathrm{c}^{+}} \mathrm{MHCII}^{+}$dendritic cells in the immune-sampling Peyer's patches [112]. L. plantarum, L. salivarius, and L. lactis attenuate Th2 responses and increase Treg frequencies in healthy mice in a strain dependent manner [113]. Oral consumption of Bifidobacterium infantis 35624 enhanced IL-10 secretion and FoxP3 expression in human peripheral blood cells pointing to the immunestimulatory effect of bifidobacteria on $\mathrm{FoxP}^{+}$iTreg induction $[114,115]$. Furthermore, it has been demonstrated that bifidobacteria stimulate TGF- $\beta$, which contributes to Treg differentiation [116].

Special attention has been paid on the critical role of the anti-inflammatory cytokine IL-10 in probiotica-induced anti-inflammatoy intestinal immune responses [110, 117, 118]. Despite heat-killing, Lactobacillus pentosus strain S-PT84 exhibited anti-allergic effects by modulating the Th1/Th2 balance and inducing Tregs [119]. Live and heatkilled Lactobacillus rhamnosus suspensions were able to induce the synthesis of different cytokines including IL-10 [120]. Heat-killed Lactobacillus acidophilus strain L-92 produced higher levels of Foxp3, IL-10 and TGF- $\beta$ compared to control mice and suppresses allergic contact dermatitis [121]. In a bovine $\beta$-lactoglobulin-sensitized mice model, oral administration of heat-killed $L$. acidophilus exhibited increased mRNA expression of Foxp3 and TGF- $\beta$ [122]. It should be noticed, that heat-treatment of probiotics may also result in a loss of immune-regulatory functions. However, the majority of studies using either native or heat-treated bifididobacteria or lactobacilli exhibits an upregulation of IL-10, TGF $\beta$ and FoxP3 [116, 119-122]. Remarkably, IL-10 potentiates differentiation of human induced Tregs via STAT3 and FoxO1 [123]. Hsu et al. [123] demonstrated that the presence of IL-10, in addition to TGF- $\beta$, leads to increased expansion of Foxp $3^{+}$iTregs with enhanced CTLA-4 expression and suppressive capability, comparable to that of natural Tregs. This process is dependent on IL-10R-mediated STAT3 signalling. Additionally, IL-10-induced inhibition of Akt phosphorylation and subsequent preservation of FoxO1 function are critical. In contrast to formula feeding, the presence of maternal milk in $\beta$-lactoglobulinsensitized rat pups exhibited an immune response profile similar to that of unchallenged dam-reared rats but with greater FoxP3 mRNA expression and $\mathrm{CD} 4^{+} \mathrm{FoxP}^{+}$cells [124]. These data may explain the preventive effect of probiotics for sensitization to common food allergens associated with a reduced incidence of atopic eczema in early childhood [125]. However, due to a lack of well-designed 
studies convincing evidence for the prevention of allergic asthma by probiotic treatment is still missing [126, 127]. The time of onset of probiotic exposure, which is physiologically natural birth and the period of breastfeeding, may play critical roles for probiotica-induced Treg maturation.

\section{Milk oligosaccharides}

Human milk contains large amounts of free oligosaccharides (HMOs). HMOs have been shown to exert anti-inflammatory properties, and evidence for their immune-modulatory effects is increasing [128-130]. A growing literature suggests that human milk contains viable bacteria [131]. McGuire et al. [131] postulated that human milk should be regarded as a probiotic food. Human milk oligosaccharides (HMOs) are minimally digested by the infant and are utilized by bifidobacteria [132]. One postulated function for these oligosaccharides is to enrich a specific "healthy" microbiota containing bifidobacteria, a genus commonly observed in the faeces of breastfed infants [133]. Recent studies show that some species of bifidobacteria are equipped with genetic and enzymatic sets dedicated to the utilization of HMOs promoting HMO-dependent growth of bifidobacteria [134]. Among gut microbes, the presence of enzymes required for degrading HMOs with type-1 chains is essentially limited to infant-gut-associated bifidobacteria, suggesting HMOs serve as selected nutrients for the bacteria pointing to a co-evolution between bifidobacteria and human beings mediated by HMOs [135]. Formula feeding in comparison to breastfeeding compromises the development of the physiological gut microbiome. In breastfed Rhesus infants Bifidobacteria and Lactobacillus predominated, whereas in formula-fed infants Ruminococcus was predominant [26]. Breastfed human infants harbour a faecal microbiota more than twice increased in Bifidobacterium numbers compared to formula-fed infants [136]. After formula feeding, Atopobium was found in significant counts and the numbers of Bifidobacteria dropped followed by increasing numbers of Bacteroides population [136]. Infant formulas containing non-digestible oligosaccharides similar to the composition in breast milk or a combination of lactic acid bacteria have been shown to harbour preventive effects towards immune-regulatory disorders [137, 138]. In fact, recent studies with whey and casein-sensitised mice showed that CD25+ ${ }^{+}$Treg contribute to the suppression of the allergic effector response in sensitised mice induced by dietary intervention with non-digestible carbohydrates $[139,140]$. Thus, it appears that milk is mammal's early life probiotic nutrient system supporting and maintaining Bifidobacteria and Lactobacillus species that induce Tregs and control immune responses.

\section{Conclusions}

Compelling evidence underlines that milk is not a simple food for infants but represents a sophisticated signalling network that promotes the differentiation and long-lasting maintenance of Tregs, the central players suppressing the development of allergy and autoimmunity. Milk provides an intricate metabolic, epigenetic, probiotic and stem cell-derived system that induces stable expression of FoxP3, the master transcription factor of Tregs. The critical allergy-preventive factor in cow's milk appears to be heat-sensitive and is abolished by boiling of milk. As amino acids and the majority of long-chain $\omega-3$ fatty acids withstand the boiling process, heat-sensitive compounds such as milk exosomes, probiotic bacteria and stem cells are the potential candidates for long-lasting Treg differentiation. In more than 200,000 million years of lactation $[141,142]$ the evolution of milk had plenty of time to create a sophisticated regulatory network optimizing the infant's Treg differentiation allowing appropriate tolerance development during the postnatal period of mammalian life. In this regard, unprocessed milk should be regarded as a conditioner for tolerance development. After birth, the newborn's immune system encounters foreign environmental antigens such as nutrients, pollens and house dust mite allergens, which via antigen-specific TCR-mediated activation induce antigen-specific Tregs. The milk-related signalling pathways presented here, may in a synergistic manner enhance antigen-specific Treg generation associated with the induction of allergen-specific immune tolerance (Fig. 1).

Most recent data underline that developing natural Treg (nTreg) cells in the thymus acquire a Treg-specific and stable hypomethylation pattern in a limited number of genes, which encode key molecules including FoxP3, essential for Treg cell function. This epigenetic change is acquired via TCR stimulation, beginning prior to FoxP3 expression. The Treg-specific DNA hypomethylated regions generally act as gene enhancers in steady state nTreg cells, contributing to the stable expression of Treg function-associated key genes including Ctla4, Il2ra, and Ikzf4 in addition to FoxP3 [143, 144]. Recent work suggests that the establishment and stability of Tregs is mediated by a number of mechanisms besides FoxP3 expression, such as epigenetic modifications, FoxO1, FoxO3a localization, expression of Eos and signalling via Neuropilin-1 [143]. To understand the pathogenesis of allergy development it is most important to characterize the immune regulatory networking of native milk. Future studies should thus focus on natural unprocessed milk and its regulatory mechanisms that support long-lasting stability of Tregs mediating livelong tolerance induction against harmless environmental antigens and autoantigens $[145,146]$. We are at the beginning to understand 
the complex interplay of milk's regulatory factors inducing and stabilizing the infant's FoxP3 expression. Yet, we have no idea about the functional priority of milk-derived factors involved in Treg lineage commitment. It is thus prudent to rely on the regulatory effectiveness of our own lactation genome, which co-evolved with the lactation-associated microbiome. Therefore, we recommend breastfeeding for adequate Treg maturation and the prevention of allergic diseases of human infants. However, for mothers who are not able to provide breast milk, human donor milk might be an alternative for appropriate Treg differentiation. Countrywide access to operating human milk banks in East Germany before Germany's unification in 1990, may explain the lower prevalence rates of atopic diseases in East versus West Germany [147, 148]. Artificial formulas still substantially differ from human breast milk. If milk exosomal microRNAs play a key role in Treg differentiation, it is of critical concern that current infant formula only contains very few human lactation-specific microRNAs [149]. The addition of bovine milk exosomal microRNAs may represent a future improvement of artificial formula feeding. Due to legal aspects and the risk of pathogen transfer, raw cow's milk can not be recommended as an agent for allergy prevention. However, in the future, it might be possible to prepare sterilized bovine milk exosomes for this purpose. It has already been shown that bovine milk exosomes increased Foxp3 expression and attenuated arthritis in two mouse models [104].

\begin{abstract}
Abbreviations
CMA: cow's milk allergy; CNS: conserved non-coding sequence; DNMT: DNA methyltransferase; FoxO: forkhead box class O; FoxP3: forkhead box P3; HMO: human milk oligosaccharides; IGF-1: insulin-like growth factor-1; IL-2: interleukin 2; IL-10: interleukin 10; microRNA: micro ribonucleic acid; mTORC1: mechanistic target of rapamycin complex 1; PI3K: phosphoinositide-3-kinase; SOCS: suppressor of cytokine signalling; STAT: signal transducer and activator of transcription; TCR: T cell receptor; TSDR: Treg-specific demethylation region; TET: ten-eleven-translocation; Treg: regulatory T-cell.
\end{abstract}

\section{Authors' contributions}

BCM performed translational research and wrote the manuscript. SMJ and PCB screened the literature and proved the data on atopy epidemiology. GS analyzed the data on exosome microRNA biology. All authors read and approved the final manuscript.

\section{Author details \\ 1 Department of Dermatology, Environmental Medicine and Health Theory, University of Osnabrück, Sedanstrasse 115, 49090 Osnabrück, Germany. \\ ${ }^{2}$ Center for Primary Health Care Research, Lund University, Lund, Sweden. \\ ${ }^{3}$ Institute for Clinical Chemistry and Laboratory Medicine, University Hospital Regensburg, University of Regensburg, Josef-Strauss-Allee 11, 93053 Regens- burg, Germany.}

\section{Competing interests}

The authors declare that they have no competing interests.

Received: 29 February 2016 Accepted: 19 April 2016

Published online: 12 May 2016
References

1. von Mutius E, Vercelli D. Farm living: effects on childhood asthma and allergy. Nat Rev Immunol. 2010;10(12):861-8.

2. Perkin MR, Strachan DP. Which aspects of the farming lifestyle explain the inverse association with childhood allergy? J Allergy Clin Immunol. 2006;117(6):1374-81.

3. Loss G, Apprich S, Waser M, Kneifel W, Genuneit J, Büchele G, et al. The protective effect of farm milk consumption on childhood asthma and atopy: the GABRIELA study. J Allergy Clin Immmunol. 2011;128(4):766-73.

4. Braun-Fahrländer $\mathrm{C}$, von Mutius E. Can farm milk consumption prevent allergic diseases? Clin Exp Allergy. 2011;41(1):29-35.

5. Illi S, Depner M, Genuneit J, Horak E, Loss G, Strunz-Lehner C, et al. Protection from childhood asthma and allergy in Alpine farm environments-the GABRIEL Advanced Studies. J Allergy Clin Immunol. 2012;129(6):1470-7.

6. Loss G, Bitter S, Wohlgensinger J, Frei R, Roduit C, Genuneit J, et al. Prenatal and early-life exposures alter expression of innate immunity genes: the PASTURE cohort study. J Allergy Clin Immunol. 2012;130(2):523-30.

7. von Mutius E. Maternal farm exposure/ingestion of unpasteurized cow's milk and allergic disease. Curr Opin Gastroenterol. 2012;28(6):570-6.

8. Wlasiuk G, Vercelli D. The farm effect, or: when, what and how a farming environment protects from asthma and allergic disease. Curr Opin Allergy Clin Immunol. 2012;12(5):461-6.

9. Lluis A, Schaub B. Lessons from the farm environment. Curr Opin Allergy Clin Immunol. 2012;12(2):158-63.

10. Sozanska B, Pearce N, Dudek K, Cullinan P. Consumption of unpasteurized milk and its effects on atopy and asthma in children and adult inhabitants in rural Poland. Allergy. 2013;68(5):644-50.

11. Lluis A, Depner M, Gaugler B, Saas P, Casaca VI, Raedler D, et al. Increased regulatory T-cell numbers are associated with farm milk exposure and lower atopic sensitization and asthma in childhood. J Allergy Clin Immunol. 2014;133(2):551-9.

12. Hoyt G, Hickey MS, Cordain L. Dissociation of the glycaemic and insulinaemic responses to whole and skimmed milk. Br J Nutr. 2005;93(2):175-7.

13. Hoppe C, Mølgaard C, Dalum C, Vaag A, Michaelsen KF. Differential effects of casein versus whey on fasting plasma levels of insulin, IGF-1 and IGF-1/IGFBP-3: results from a randomized 7-day supplementation study in prepubertal boys. Eur J Clin Nutr. 2009;63(9):1076-83.

14. Nilsson M, Stenberg M, Frid AH, Holst JJ, Björck IM. Glycemia and insulinemia in healthy subjects after lactose-equivalent meals of milk and other food proteins: the role of plasma amino acids and incretins. Am J Clin Nutr. 2004;80(5):1246-53.

15. Nilsson M, Holst JJ, Björck IM. Metabolic effects of amino acid mixtures and whey protein in healthy subjects: studies using glucose-equivalent drinks. Am J Clin Nutr. 2007:85(4):996-1004.

16. Salehi A, Gunnerud U, Muhammed SJ, Ostman E, Holst JJ, Björck I, et al. The insulinogenic effects of whey protein is partially mediated by a direct effect of amino acids and GIP on $\beta$-cells. Nutr Metab (Lond). 2012;9(1):48.

17. Wheelhouse NM, Stubbs AK, Lomax MA, MacRae JC, Hazlerigg DG. Growth hormone and amino acid supply interact synergistically to control insulin-like growth factor-l production and gene expression in cultured ovine hepatocytes. J Endocrinol. 1999;163(2):353-61.

18. Stubbs AK, Wheelhouse NM, Lomax MA, Hazlerigg DG. Nutrient-hormone interaction in the ovine liver: methionine supply selectively modulates growth hormone-induced IGF-I gene expression. J Endocrinol. 2002;174(2):335-41.

19. Rich-Edwards JW, Ganmaa D, Pollak MN, Nakamoto EK, Kleinman K, Tserendolgor $\mathrm{U}$, et al. Milk consumption and the prepubertal somatotropic axis. Nutr J. 2007;6:28.

20. Rzehak P, Grote V, Lattka E, Weber M, Gruszfeld D, Socha P, et al. Associations of IGF-1 gene variants and milk protein intake with IGF-I concentrations in infants at age 6 months - results from a randomized clinical trial. Growth Horm IGF Res. 2013;23(5):149-58.

21. Fleddermann $M$, Demmelmair $H$, Grote $V$, Bidlingmaier $M$, Grimminger P, Bielohuby M, et al. Role of selected amino acids on plasma IGF-I concentration in infants. Eur J Nutr. 2015; [Epub ahead of print]. 
22. Huynh A, Zhang R, Turka LA. Signals and pathways controlling regulatory T cells. Immunol Rev. 2014;258(1):117-31.

23. Huynh A, DuPage M, Priyadharshini B, Sage PT, Quiros J, Borges CM, et al. Control of PI(3) kinase in Treg cells maintains homeostasis and lineage stability. Nat Immunol. 2015;16(2):188-96.

24. Axelsson IE, Ivarsson SA, Räihä NC. Protein intake in early infancy: effects on plasma amino acid concentrations, insulin metabolism, and growth. Pediatr Res. 1989;26(6):614-7.

25. Socha P, Grote V, Gruszfeld D, Janas R, Demmelmair H, Closa-Monasterolo R, et al. Milk protein intake, the metabolic-endocrine response, and growth in infancy: data from a randomized clinical trial. Am J Clin Nutr. 2011;94(6 Suppl):1776S-84S

26. O'Sullivan A, He X, McNiven EM, Haggarty NW, Lönnerdal B, Slupsky CM. Early diet impacts infant Rhesus gut microbiome, immunity, and metabolism. J Proteome Res. 2013;12(6):2833-45.

27. Litonjua AA, Gold DR. Asthma and obesity: common early-life influences in the inception of disease. J Allergy Clin Immunol. 2008:121(5):1075-84.

28. Paul IM, Camera L, Zeiger RS, Guilbert TW, Bacharier LB, Taussig LM, et al. Relationship between infant weight gain and later asthma. Pediatr Allergy Immunol. 2010;21 (1 Pt 1):82-9.

29. Brüske I, Flexeder C, Heinrich J. Body mass index and the incidence of asthma in children. Curr Opin Allergy Clin Immunol. 2014;14(2):155-60.

30. Haque $R$, Lei F, Xiong $X$, Song J. The regulation of FoxP3-expressing regulatory T cells. Endocr Metab Immune Disord Drug Targets. 2011;11(4):334-46.

31. Ohkura N, Kitagawa Y, Sakaguchi S. Development and maintenance of regulatory T cells. Immunity. 2013;38(3):414-23.

32. Passerini L, Santoni de Sio FR, Roncarolo MG, Bacchetta R. Forkhead box P3: the peacekeeper of the immune system. Int Rev Immunol. 2014;33(2):129-45.

33. van Nieuwenhuijze A, Liston A. The molecular control of regulatory $T$ cell induction. Prog Mol Biol Transl Sci. 2015;136:69-97.

34. Elkord E. Role of regulatory $T$ cells in allergy: implications for therapeutic strategy. Inflamm Allergy Drug Targets. 2006;5(4):211-7.

35. Nouri-Aria KT, Durham SR. Regulatory T cells and allergic disease. Inflamm Allergy Drug Targets. 2008;7(4):237-52.

36. Zhang H, Kong H, Zeng X, Guo L, Sun X, He S. Subsets of regulatory T cells and their roles in allergy. J Transl Med. 2014;12:125.

37. Palomares O, Yaman G, Azkur A, Akkoc T, Akdis M, Akdis CA. Role of Treg in immune regulation of allergic diseases. Eur J Immunol. 2010;40(5):1232-40.

38. Pellerin L, Jenks JA, Bégin P, Bacchetta R, Nadeau KC. Regulatory T cells and their roles in immune dysregulation and allergy. Immunol Res. 2014;58(2-3):358-68.

39. Robinson DS. Regulatory T cells and asthma. Clin Exp Allergy. 2009:39(9):1314-23

40. Harada Y, Harada Y, Elly C, Ying G, Paik JH, DePinho RA, et al. Transcription factors Foxo3a and Foxol couple the E3 ligase Cbl-b to the induction of Foxp3 expression in induced regulatory T cells. J Exp Med. 2010;207(7):1381-91.

41. Kerdiles YM, Stone EL, Beisner DR, McGargill MA, Ch'en IL, Stockmann C, et al. Foxo transcription factors control regulatory $T$ cell development and function. Immunity. 2010:33(6):890-904.

42. Merkenschlager M, von Boehmer H. PI3 kinase signalling blocks Foxp3 expression by sequestering Foxo factors. J Exp Med. 2010;207(7):1347-50.

43. Ouyang W, Beckett O, Ma Q, Paik JH, DePinho RA, Li MO. Foxo proteins cooperatively control the differentiation of Foxp $3^{+}$regulatory T cells. Nat Immunol. 2010;11(7):618-27.

44. Ouyang W, Liao W, Luo CT, Yin N, Huse M, Kim MV, et al. Novel Foxo 1dependent transcriptional programs control T(reg) cell function. Nature. 2012;491 (7425):554-9.

45. Efeyan A, Zoncu R, Sabatini DM. Amino acids and mTORC1: from lysosomes to disease. Trends Mol Med. 2012;18(9):524-33.

46. Jewell JL, Russell RC, Guan KL. Amino acid signalling upstream of mTOR. Nat Rev Mol Cell Biol. 2013;14(3):133-9.

47. Bar-Peled L, Sabatini DM. Regulation of mTORC1 by amino acids. Trends Cell Biol. 2014;24(7):400-6.
48. Melnik BC, John SM, Schmitz G. Milk is not just food but most likely a genetic transfection system activating mTORC1 signaling for postnatal growth. Nutr J. 2013;12:103

49. Melnik BC. Milk—a nutrient system of mammalian evolution promoting mTORC1- dependent translation. Int J Mol Sci. 2015;16(8):17048-87.

50. Wu J, de Theije CG, da Silva SL, van der Horst H, Reinders MT, Broersen LM, et al. mTOR plays an important role in cow's milk allergy-associated behavioral and immunological deficits. Neuropharmacology. 2015;97:220-32.

51. Haxhinasto $S$, Mathis D, Benoist C. The AKT-mTOR axis regulates de novo differentiation of $\mathrm{CD}^{+}{ }^{+} \mathrm{FoxP}^{+}$cells. J Exp Med. 2008;205(3):565-74.

52. Sauer S, Bruno L, Hertweck A, Finlay D, Leleu M, Spivakov M, Knight ZA, et al. T cell receptor signaling controls FoxP3 expression via PI3K, Akt, and mTOR. Proc Natl Acad Sci USA. 2008;105(22):7797-802.

53. Delgoffe GM, Kole TP, Zheng Y, Zarek PE, Matthews KL, Xiao B, Worley PF, et al. The mTOR kinase differentially regulates effector and regulatory $T$ cell lineage commitment. Immunity. 2009;30(6):832-44.

54. Melnik BC. Excessive leucine-mTORC1-signalling of cow milk-based infant formula: the missing link to understand early childhood obesity. J Obes. 2012;2012:197653.

55. Melnik BC. The potential mechanistic link between allergy and obesity development and infant formula feeding. Allergy Asthma Clin Immunol. 2014;10(1):37.

56. Brick T, Schober Y, Böcking C, Pekkanen J, Genuneit J, Loss G, et al. $\omega$-3 fatty acids contribute to the asthma-protective effect of unprocessed cow's milk. J Allergy Clin Immunol. 2016. doi:10.1016/j.jaci.2015.10.042

\section{[Epub ahead of print]}

57. Haitz KA, Anandasabapathy N. Docosahexaenoic acid alleviates atopic dermatitis in mice by generating T regulatory cells and $\mathrm{m} 2 \mathrm{mac}-$ rophages. J Invest Dermatol. 2015;135(6):1472-4.

58. Han SC, Koo DH, Kang NJ, Yoon WJ, Kang GJ, Kang HK, et al. Docosahexaenoic acid alleviates atopic dermatitis by generating Tregs and IL-10/ TGF- $\beta$-modified macrophages via a TGF- $\beta$-dependent mechanism. J Invest Dermatol. 2015;135(6):1556-64.

59. Yasuda M, Tanaka Y, Kume S, Morita Y, Chin-Kanasaki M, Araki H, et al. Fatty acids are novel nutrient factors to regulate mTORC1 lysosomal localization and apoptosis in podocytes. Biochim Biophys Acta. 2014;1842(7):1097-108.

60. van den Elsen LW, Meulenbroek LA, van Esch BC, Hofman GA, Boon L, Garssen J, et al. CD25+ regulatory T cells transfer $\mathrm{n}-3$ long chain polyunsaturated fatty acids-induced tolerance in mice allergic to cow's milk protein. Allergy. 2013;68(12):1562-70.

61. de Candia P, De Rosa V, Casiraghi M, Matarese G. Extracellular RNAs: a secret arm of immune system regulation. J Biol Chem. 2016;291(14):7221-8.

62. McCoy-Simandle K, Hanna SJ, Cox D. Exosomes and nanotubes: control of immune cell communication. Int J Biochem Cell Biol. 2016;71:44-54.

63. Weber JA, Baxter DH, Zhang S, Huang DY, Huang KH, Lee MJ, et al. The microRNA spectrum in 12 body fluids. Clin Chem. 2010;56(11):1733-41.

64. Zhu H, Fan GC. Extracellular/circulating microRNAs and their potential role in cardiovascular disease. Am J Cardiovasc Dis. 2011;1(2):138-49.

65. Chen X, Liang H, Zhang J, Zen K, Zhang CY. Horizontal transfer of microRNAs: molecular mechanisms and clinical applications. Protein Cell. 2012;3(1):28-37.

66. Rayner KJ, Hennessy EJ. Extracellular communication via microRNA lipid particles have a new message. J Lipid Res. 2013;54(5):1174-81.

67. Boon RA, Vickers KC. Intercellular transport of microRNAs. Arterioscler Thromb Vasc Biol. 2013;33(2):186-92.

68. Zhou Q, Li M, Wang X, Li Q, Wang T, Zhu Q, et al. Immune-related microRNAs are abundant in breast milk exosomes. Int J Biol Sci. 2012;8(1):118-23.

69. Izumi H, Tsuda M, Sato Y, Kosaka N, Ochiya T, I wamoto H, et al. Bovine milk exosomes contain microRNA and mRNA and are taken up by human macrophages. J Dairy Sci. 2015;98(5):2920-33.

70. Gu Y, Li M, Wang T, Liang Y, Zhong Z, Wang X, et al. Lactation-related microRNA expression profiles of porcine breast milk exosomes. PLoS One. 2012;7(8):e43691.

71. Alsaweed M, Lai CT, Hartmann PE, Geddes DT, Kakulas F. Human milk miRNAs primarily originate from the mammary gland resulting in unique miRNA profiles of fractionated milk. Sci Rep. 2016;6:20680 
72. Melnik BC, John SM, Schmitz G. Milk: an exosomal microRNA transmitter promoting thymic regulatory $T$ cell maturation preventing the development of atopy. J Transl Med. 2014;12:43.

73. Polansky JK, Kretschmer K, Freyer J, Floess S, Garbe A, Baron U, et al. DNA methylation controls Foxp3 gene expression. Eur J Immunol. 2008;38(6):1654-63.

74. Polansky JK, Schreiber L, Thelemann C, Ludwig L, Krüger M, Baumgrass $R$, et al. Methylation matters: binding of Ets-1 to the demethylated Foxp3 gene contributes to the stabilization of Foxp3 expression in regulatory T cells. J Mol Med (Berl). 2010;88(10):1029-40.

75. Toker A, Engelbert D, Garg G, Polansky JK, Floess S, Miyao T, et al. Active demethylation of the Foxp3 locus leads to the generation of stable regulatory T cells within the thymus. J Immunol. 2013;190(7):3180-8.

76. Bacchetta R, Gambineri E, Roncarolo MG. Role of regulatory T cells and FOXP3 in human diseases. J Allergy Clin Immunol. 2007;120(2):227-35.

77. Nadeau K, McDonald-Hyman C, Noth EM, Pratt B, Hammond SK, Balmes $J$, et al. Ambient air pollution impairs regulatory T-cell function in asthma. J Allergy Clin Immunol. 2010;126(4):845-52.

78. Hinz D, Bauer M, Röder S, Olek S, Huehn J, Sack U, et al. Cord blood Tregs with stable FOXP3 expression are influenced by prenatal environment and associated with atopic dermatitis at the age of one year. Allergy. 2012;67(3):380-9.

79. Koh KP, Rao A. DNA methylation and methylcytosine oxidation in cell fate decisions. Curr Opin Cell Biol. 2013;25(2):152-61.

80. Ko M, Bandukwala HS, Chavez L, Aijö T, Pastor WA, Segal MF, et al. Modulation of TET2 expression and 5-methylcytosine oxidation by the CXXC domain protein IDAX. Nature. 2013;497(7447):122-6.

81. Dunican DD, Pennings S, Meeha RR. The CXXC-TET bridge-mind the methylation gap! Cell Res. 2013;23(8):973-4.

82. Josefowicz SZ, Wilson CB, Rudensky AY. Cutting edge: TCR stimulation is sufficient for induction of Foxp3 expression in the absence of DNA methyltransferase 1. J Immunol. 2009;182(11):6648-52.

83. Lal G, Bromberg JS. Epigenetic mechanisms of regulation of Foxp3 expression. Blood. 2009;114(18):3727-35.

84. Pan W, Zhu S, Yuan M, Cui H, Wang L, Luo X, et al. MicroRNA-21 and microRNA-148a contribute to DNA hypomethylation in Lupus CD4 ${ }^{+}$ T cells by directly and indirectly targeting DNA methyltransferase 1. J Immunol. 2010;184(12):6773-81.

85. Chen X, Gao C, Li H, Huang L, Sun Q, Dong Y, et al. Identification and characterization of microRNAs in raw milk during different periods of lactation, commercial fluid, and powdered milk products. Cell Res. 2010;20(10):1128-37.

86. Izumi H, Kosaka N, Shimizu T, Sekine K, Ochiya T, Takase M. Bovine milk contains microRNA and messenger RNA that are stable under degradative conditions. J Dairy Sci. 2012;95(9):4831-41.

87. Kirchner B, Pfaffl MW, Dumpler J, von Mutius E, Ege MJ. microRNA in native and processed cow's milk and ist implication fort he farm milk effect on asthma. J Allergy Clin Immunol. 2015. doi:10.1016/j. jaci.2015.10.028 [Epub ahead of print].

88. Munch EM, Harris RA, Mohammad M, Benham AL, Pejerrey SM, Showalter $L$, et al. Transcriptome profiling of microRNA by Next-Gen deep sequencing reveals known and novel miRNA species in the lipid fraction of human breast milk. PLoS One. 2013;8(2):e50564.

89. Baier SR, Nguyen C, Xie F, Wood JR, Zempleni J. MicroRNAs are absorbed in biologically meaningful amounts from nutritionally relevant doses of cow milk and affect gene expression in peripheral blood mononuclear cells, HEK-293 kidney cell cultures, and mouse livers. J Nutr. 2014;144(10):1495-500.

90. Fabbri M, Garzon R, Cimmino A, Liu Z, Zanesi N, Callegari E, et al. MicroRNA-29 family reverts aberrant methylation in lung cancer by targeting DNA methyltransferases $3 \mathrm{~A}$ and 3B. Proc Natl Acad Sci USA. 2007;104(40):15805-10.

91. Reinhardt TA, Lippolis JD, Nonnecke BJ, Sacco RE. Bovine milk exosome proteome. J Proteomics. 2012;75(5):1486-92.

92. Zhang J, Li S, Li L, Li M, Guo C, Yao J, et al. Exosome and exosomal microRNA: trafficking, sorting, and function. Genomics Proteomics Bioinform. 2015;13(1):17-24.

93. Alsaweed M, Hartmann PE, Geddes DT, Kakulas F. MicroRNAs in breastmilk and the lactating breast: potential immunoprotectors and developmental regulators for the infant and the mother. Int J Environ Res Public Health. 2015;12(11):13981-4020.
94. Wolf T, Baier SR, Zempleni J. The intestinal transport of bovine milk exosomes is mediated by endocytosis in human colon carcinoma Caco-2 cells and rat small intestinal IEC-6 cells. J Nutr. 2015; 145(10):2201-6.

95. Kusuma RJ, Manca S, Friemel T, Sukreet S, Nguyen C, Zempleni J. Human vascular endothelial cells transport foreign exosomes from cow's milk by endocytosis. Am J Physiol Cell Physiol. 2016. doi:10.1152/ ajpcell.00169.2015 [Epub ahead of print].

96. Yao R, Ma YL, Liang W, Li HH, Ma ZJ, Yu X, et al. MicroRNA-155 modulates Treg and Th17 cells differentiation and Th17 cell function by targeting SOCS1. PLoS One. 2012;7(10):e46082.

97. Pieters BC, Arntz OJ, Bennink MB, Broeren MG, van Caam AP, Koenders $\mathrm{Ml}$, et al. Commercial cow milk contains physically stable extracellular vesicles expressing immunoregulatory TGF- $\beta$. PLoS One. 2015; 10(3):e0121123.

98. Moustakas A, Heldin $\mathrm{CH}$. The regulation of TGFbeta signal transduction. Development. 2009;136(22):3699-714.

99. Heldin $\mathrm{CH}$, Moustakas A. Role of Smads in TGF $\beta$ signaling. Cell Tissue Res. 2012;347(1):21-36.

100. Huehn J, Beyer M. Epigenetic and transcriptional control of Foxp3 ${ }^{+}$ regulatory T cells. Semin Immunol. 2015;27(1):10-8.

101. Chen W, Konkel JE. Development of thymic Foxp3(+) regulatory T cells: TGF- $\beta$ matters. Eur J Immunol. 2015;45(4):958-65.

102. Tran DQ. TGF- $\beta$ : the sword, the wand, and the shield of FOXP3 $(+)$ regulatory T cells. J Mol Cell Biol. 2012;4(1):29-37.

103. Luo X, Zhang Q, Liu V, Xia Z, Pothoven KL, Lee C. Cutting edge: TGFbeta-induced expression of Foxp3 in T cells is mediated through inactivation of ERK. J Immunol. 2008;180(5):2757-61.

104. Arntz OJ, Pieters BC, Oliveira MC, Broeren MG, Bennink MB, de Vries $M$, et al. Oral administration of bovine milk derived extracellular vesicles attenuates arthritis in two mouse models. Mol Nutr Food Res. 2015;59(9):1701-12.

105. Wang GJ, Liu Y, Qin A, Shah SV, Deng ZB, Xiang X, et al. Thymus exosomes-like particles induce regulatory $T$ cells. J Immunol. 2008;181(8):5242-8

106. Admyre C, Johansson SM, Qazi KR, Filén JJ, Lahesmaa R, Norman M, et al. Exosomes with immune modulatory features are present in human breast milk. J Immunol. 2007;179(3):1969-78.

107. Bian Y, Terse A, Du J, Hall B, Molinolo A, Zhang P, et al. Progressive tumor formation in mice with conditional deletion of TGF-beta signaling in head and neck epithelia is associated with activation of the PI3K/Akt pathway. Cancer Res. 2009;69(14):5918-26.

108. Martín R, Jiménez E, Heilig H, Fernández L, Marín ML, Zoetendal EG, et al. Isolation of bifidobacteria from breast milk and assessment of the bifidobacterial population by PCR-denaturing gradient gel electrophoresis and quantitative real-time PCR. Appl Environ Microbiol. 2009;75(4):965-9.

109. Urbaniak C, Angelini M, Gloor GB, Reid G. Human milk microbiota profiles in relation to birthing method, gestation and infant gender. Microbiome. 2016;4(1):1.

110. Jiang M, Zhang F, Wan C, Xiong Y, Shah NP, Wei H, et al. Evaluation of probiotic properties of Lactobacillus plantarum WLPL04 isolated from human breast milk. J Dairy Sci. 2016. doi:10.3168/jds.2015-10434 [Epub ahead of print].

111. Urbaniak C, Burton JP, Reid G. Breast, milk and microbes: a complex relationship that does not end with lactation. Womens Health (Lond Engl). 2012;8(4):385-98.

112. Smelt MJ, de Haan BJ, Bron PA, van Swam I, Meijerink M, Wells JM, et al. Probiotics can generate FoxP3 T-cell responses in the small intestine and simultaneously inducing CD4 and CD8 T cell activation in the large intestine. PLoS One. 2013;8(7):e68952.

113. Smelt MJ, de Haan BJ, Bron PA, van Swam I, Meijerink M, Wells JM, et al. L. plantarum, L. salivarius, and L. lactis attenuate Th2 responses and increase Treg frequencies in healthy mice in a strain dependent manner. PLoS One. 2012;7(10):e47244.

114. Konieczna P, Akdis CA, Quigley EM, Shanahan F, O'Mahony L. Portrait of an immunoregulatory Bifidobacterium. Gut Microbes. 2012;3(3):261-6.

115. Konieczna P, Groeger D, Ziegler M, Frei R, Ferstl R, Shanahan F, et al. Bifidobacterium infantis 35624 administration induces Foxp3 T regulatory cells in human peripheral blood: potential role for myeloid and plasmacytoid dendritic cells. Gut. 2012;61(3):354-66. 
116. Donkor ON, Ravikumar M, Proudfoot O, Day SL, Apostolopoulos V, Paukovics $\mathrm{G}$, et al. Cytokine profile and induction of T helper type 17 and regulatory $T$ cells by human peripheral mononuclear cells after microbial exposure. Clin Exp Immunol. 2012;167(2):282-95.

117. de Moreno de Leblanc A, Del Carmen S, Zurita-Turk M, Santos Rocha C, van de Guchte M, Azevedo V, et al. Importance of IL-10 modulation by probiotic microorganisms in gastrointestinal inflammatory diseases. ISRN Gastroenterol. 2011;2011:892971

118. Demont A, Hacini-Rachinel F, Doucet-Ladevèze R, Ngom-Bru C, Mercenier A, Prioult G, et al. Live and heat-treated probiotics differently modulate IL10 mRNA stabilization and microRNA expression. J Allergy Clin Immunol. 2016;137:1264-7.

119. Nonaka Y, Izumo T, Izumi F, Maekawa T, Shibata H, Nakano A, et al. Antiallergic effects of Lactobacillus pentosus strain S-PT84 mediated by modulation of Th1/Th2 immunobalance and induction of IL-10 production. Int Arch Allergy Immunol. 2008;145(3):249-57.

120. Jorjão $A L$, de Oliveira FE, Leão MV, Carvalho CA, Jorge AO, de Oliveira LD. Live and heat-killed Lactobacillus rhamnosus ATCC 7469 may induce modulatory cytokines profiles on macrophages RAW 264.7. ScientificWorld Journal. 2015:2015:716749.

121. Shah MM, Saio M, Yamashita H, Tanaka H, Takami T, Ezaki T, et al. Lactobacillus acidophilus strain L-92 induces CD4(+)CD25(+)Foxp3(+) regulatory $T$ cells and suppresses allergic contact dermatitis. Biol Pharm Bull. 2012;35(4):612-6.

122. Li AL, Meng XC, Duan CC, Huo GC, Zheng QL, Li D. Suppressive effects of oral administration of heat-killed Lactobacillus acidophilus on T helper-17 immune responses in a bovine $\beta$-lactoglobulin-sensitized mice model. Biol Pharm Bull. 2013;36(2):202-7.

123. Hsu P, Santner-Nanan B, Hu M, Skarratt K, Lee CH, Stormon M, et al. IL-10 potentiates differentiation of human induced regulatory $T$ cells via STAT3 and Foxo1. J Immunol. 2015:195(8):3665-74.

124. Tooley KL, El-Merhibi A, Cummins AG, Grose RH, Lymn KA, DeNichilo $M$, et al. Maternal milk, but not formula, regulates the immune response to beta-lactoglobulin in allergy-prone rat pups. J Nutr. 2009;139(11):2145-51.

125. Allen SJ, Jordan S, Storey M, Thornton CA, Gravenor MB, Garaiova I, et al. Probiotics in the prevention of eczema: a randomised controlled trial. Arch Dis Child. 2014;99(11):1014-9.

126. West CE. Gut microbiota and allergic disease: new findings. Curr Opin Clin Nutr Metab Care. 2014;17(3):261-6.

127. West CE, Jenmalm MC, Kozyrskyj AL, Prescott SL. Probiotics for treatment and primary prevention of allergic diseases and asthma: looking back and moving forward. Expert Rev Clin Immunol. 2016 [Epub ahead of print].

128. Eiwegger T, Stahl B, Schmitt J, Boehm G, Gerstmayr M, Pichler J, et al. Human milk-derived oligosaccharides and plant-derived oligosaccharides stimulate cytokine production of cord blood T-cells in vitro. Pediatr Res. 2004;56(4):536-40

129. Eiwegger T, Stahl B, Haidl P, Schmitt J, Boehm G, Dehlink E, et al. Prebiotic oligosaccharides: in vitro evidence for gastrointestinal epithelial transfer and immunomodulatory properties. Pediatr Allergy Immunol. 2010;21(8):1179-88.

130. Castanys-Muñoz E, Martin MJ, Vazquez E. Building a beneficial microbiome from birth. Adv Nutr. 2016;7(2):323-30.

131. McGuire MK, McGuire MA. Human milk: mother nature's prototypical probiotic food? Adv Nutr. 2015;6(1):112-23.

132. Sela DA, Mills DA. Nursing our microbiota: molecular linkages between bifidobacteria and milk oligosaccharides. Trends Microbiol. 2010;18(7):298-307.
133. Zivkovic AM, German JB, Lebrilla CB, Mills DA. Human milk glycobiome and its impact on the infant gastrointestinal microbiota. Proc Natl Acad Sci USA. 2011;108(Suppl 1):4653-8.

134. Asakuma S, Hatakeyama E, Urashima T, Yoshida E, Katayama T, Yamamoto K, et al. Physiology of consumption of human milk oligosaccharides by infant gut-associated bifidobacteria. J Biol Chem. 2011:286(40):34583-92.

135. Katayama T. Host-derived glycans serve as selected nutrients for the gut microbe: human milk oligosaccharides and bifidobacteria. Biosci Biotechnol Biochem. 2016;3:1-12.

136. Bezirtzoglou E, Tsiotsias A, Welling GJ. Microbiota profile in feces of breast- and formula-fed newborns by using in situ hybridization (FISH). Anaerobe. 2011;17(6):478-82

137. Kerperien J, Jeurink PV, Wehkamp T, van der Veer A, van de Kant HJ, Hofman GA, et al. Non-digestible oligosaccharides modulate intestinal immune activation and suppress cow's milk allergic symptoms. Pediatr Allergy Immunol. 2014;25(8):747-54.

138. Lehmann S, Hiller J, van Bergenhenegouwen J, Bergenhenegouwen LM, Garssen J, Traidl-Hoffmann C. In vitro evidence for immunemodulatory properties of non-digestible oligosaccharides: direct effect on human monocyte derived dendritic cells. PLoS One. 2015:10(7):e0132304.

139. Schouten B, van Esch BC, Hofman GA, Boon L, Knippels LM, Willemsen $L E$, et al. Oligosaccharide-induced whey-specific CD25(+) regulatory T-cells are involved in the suppression of cow milk allergy in mice. J Nutr. 2010;140(4):835-41.

140. Schouten B, van Esch BC, Hofman GA, de Kivit S, Boon L, Knippels LM, et al. A potential role for $C D 25^{+}$regulatory T-cells in the protection against casein allergy by dietary non-digestible carbohydrates. $\mathrm{Br} \mathrm{J}$ Nutr. 2012;107(1):96-105.

141. Capuco AV, Akers RM. The origin and evolution of lactation. J Biol. 2009;8(4):37.

142. Lefèvre CM, Sharp JA, Nicholas KR. Evolution of lactation: ancient origin and extreme adaptations of the lactation system. Annu Rev Genomics Hum Genet. 2010;11:219-38.

143. Morikawa H, Sakaguchi S. Genetic and epigenetic basis of Treg cell development and function: from a FoxP3-centered view to an epigenome-defined view of natural Treg cells. Immunol Rev. 2014;259(1):192-205.

144. Kitagawa Y, Ohkura N, Sakaguchi S. Epigenetic control of thymic Tregcell development. Eur J Immunol. 2015;45(1):11-6.

145. Li X, Zheng Y. Regulatory T cell identity: formation and maintenance. Trends Immunol. 2015;36(6):344-53.

146. Overacre AE, Vignali DA. Treg stability: to be or not to be. Curr Opin Immunol. 2016;39:39-43.

147. Trepka MJ, Heinrich J, Wichmann HE. The epidemiology of atopic diseases in Germany: an east-west comparison. Rev Environ Health. 1996;11(3):119-31.

148. Weiland SK, von Mutius E, Hirsch T, Duhme H, Fritzsch C, Werner B, et al. Prevalence of respiratory and atopic disorders among children in the East and West of Germany five years after unification. Eur Respir J. 1999;14(4):862-70.

149. Alsaweed M, Lai CT, Hartmann PE, Geddes DT, Kakulas F. Human milk miRNAs primarily originate from the mammary gland resulting in unique miRNA profiles of fractionated milk. Sci Rep. 2016;8(6):20680. doi:10.1038/srep20680. 